\title{
UNIVERSITYOF
}

FORWARD

THINKING

WESTMINSTER用

WestminsterResearch

http://www.westminster.ac.uk/westminsterresearch

The ASEAN community-based tourism standards: looking

beyond certification

Novelli, M., Klatte, N. and Dolezal, C.

This is an Accepted Manuscript of an article published by Taylor \& Francis in Tourism Planning \& Development, 14 (2), pp. 260-281. The final definitive version is available online:

https://dx.doi.org/10.1080/21568316.2016.1243146

(c) 2016 Taylor \& Francis

The WestminsterResearch online digital archive at the University of Westminster aims to make the research output of the University available to a wider audience. Copyright and Moral Rights remain with the authors and/or copyright owners.

Whilst further distribution of specific materials from within this archive is forbidden, you may freely distribute the URL of WestminsterResearch: ((http://westminsterresearch.wmin.ac.uk/)).

In case of abuse or copyright appearing without permission e-mail repository@westminster.ac.uk 
Tourism Planning \& Development
Routledge

Taylor \& Francis Group

\section{The ASEAN Community-Based Tourism Standards: looking} beyond certification.

\begin{tabular}{|r|l|}
\hline Journal: & Tourism Planning \& Development \\
\hline Manuscript ID & Draft \\
\hline Manuscript Type: & article \\
\hline Keywords: & $\begin{array}{l}\text { ASEAN, benchmarking, certification, community-based tourism, standards, } \\
\text { Sustainable Tourism }\end{array}$ \\
\hline
\end{tabular}

SCHOLARONE ${ }^{\text {"x }}$

Manuscripts

URL: http://mc.manuscriptcentral.com/rthp 


\title{
The ASEAN Community-Based Tourism Standards: looking beyond certification.
}

\begin{abstract}
This paper reports findings from an opportunity study on the appropriateness of implementing community-based tourism standards (CBTS) certification through the Association of Southeast Asian Nations (ASEAN) criteria, as a way to improve sustainable tourism provision in the region. Framed by critical reflections on community-based tourism (CBT) literature and existing sustainable tourism standards (STS) practices, qualitative research consisting of interviews with six key industry experts provided core insights into a number of CBTS' implementation challenges. Findings indicate the main hindering factors for the implementation of CBTS to be the lack of adequate governance, limited funding and insufficient community capacity. The study concluded that although at the moment the full implementation of CBTS as a certification programme would be premature, ASEAN-CBTS' criteria are a useful benchmarking and strategic planning tool for local communities, which would eventually lead to improved CBT benefits, standards and performance in the region. At the same time, this paper argues that aspects including CBT competitiveness and service delivery need to be tackled first to create fruitful grounding for CBT certification.
\end{abstract}

\section{Introduction}

During the last three decades, the concept of sustainability has permutated into people's consciousness, government policies and development strategies, with community-based tourism (CBT) as one of the widely sought after alternative and sustainable tourism solutions. Despite its variable levels of successes around the world (Novelli, 2016), in South East Asia, CBT has been portrayed as one of the most meaningful and supportive ways to enhance 
community development and income generation for marginalised communities - even if it often comes with criticisms relating to local power inequalities, participation and lack of local capacity (Dolezal, 2015a, 2015b). A proliferating number of international development agencies (IDAs) and NGOs explicitly engage with CBT with the specific mandate to assist communities in understanding the concept, benefits and opportunities, as well as dealing with its implementation challenges.

In response to the growth of CBT in the region, the Association of Southeast Asian Nations ${ }^{\text {, }}$ (ASEAN) tourism ministries joined forces in their plea for the development of common regional community-based tourism standards (CBTS) with their primary objective to promote a more sustainable approach in the planning and development of CBT. The present research investigates these standards and is framed by critical reflections on CBT literature and existing sustainable tourism standards (STS) practices, namely the Sustainable Tourism Criteria Initiative, Green Globe and the CBTS of the Community-Based Tourism Institute Thailand (also referred to as CBT-I standards) and offers key findings from qualitative research conducted with industry experts. This paper critically assesses the appropriateness of ASEAN-CBTS as a certification tool and reflects upon its implementation challenges, opportunities and attempts to contribute to the broader debate on CBT planning and development in the ASEAN context.

\footnotetext{
${ }^{1}$ ASEAN is the acronym used to refer to the Association of Southeast Asian Nations, which was established on 8 August 1967 in Bangkok (Thailand), where the ASEAN Declaration (or Bangkok Declaration) was signed by its founder members, namely Indonesia, Malaysia, Philippines, Singapore and Thailand. Brunei Darussalam later joined on 7 January 1984, Viet Nam on 28 July 1995, Lao PDR and Myanmar on 23 July 1997, and Cambodia on 30 April 1999, making up what is today the ten Member States of ASEAN (ASEAN, 2014).
} 
A number of challenges emerged primarily associated with the lack of adequate governance, limited funding and insufficient capacity within the community. These factors all contribute to hindering the successful implementation of CBTS. The study identified that although the implementation of an ASEAN-CBTS regional certification was a premature objective, its criteria are a useful benchmarking and strategic planning tool for local communities, which would eventually lead to improved CBT benefits, standards and performance in the region.

\section{Community Based Tourism - A Critical Overview}

Generally proposed as an approach to foster community development in developing countries, CBT finds its roots in the 1970s' ambition of involving communities in bottom-up development (Reid, Mair \& George, 2004). This idea was first championed in tourism by Murphy (1983, 1985, 1988), through his 'community-driven tourism planning' propositions associated with a developed country context, which evolved into todays' CBT, happening mainly, but not only, in the developing world. CBT has become the focus of a rich body of studies critiquing its concept and application, as well as a set of case studies from developing nations in the Asia-Pacific region, the Middle East, South America and Africa (Aref, 2011; Erskine \& Meyer, 2012; Snyman, 2012a, 2012b; Wearing \& McDonald, 2002). CBT is generally understood as encompassing the active participation of communities in the planning, implementation and management of tourism in order to provide wider benefits for the community (Goodwin \& Santilli, 2009) than would traditionally have been the case. Notwithstanding its value, CBT models have been criticised for being overly reliant on Western ideas of development, which inform the agendas of IDAs, governments and NGO's with little attention being paid to local views and knowledge (Le, Weaver \& Lawton,2012). 
CBT has been used as a rural diversification strategy for community development, especially in those remote areas characterized by limited alternatives for economic development. Whilst it has been praised for fostering essential rural grassroots community participation in tourism development (Moscardo, 2008; Leksakundilok \& Hirsch, 2008; Rocharungsat, 2008), it has also been criticised for providing incongruent objectives and raising unachievable expectations for local socio-economic growth (Goodwin \& Santilli, 2009; Scheyvens, 2002) or for being a mere 'window dressing exercise' (Novelli \& Gebhardt, 2007). In some cases, the lack of community involvement in the planning process has led to inter-community conflict and tensions (Reid, et al., 2004; Stoeckl, 2008) and unequal power relations between villagers themselves but also between villagers and ouside actors (Dolezal, 2015a). If CBT "is intended to maximise the participation of local people in decision making from a very early stage" (Smith \& Duffy, 2003, p. 138) communities need to be integrated in the planning process, so that they can gain power and responsibility to decide on the direction and the nature of the tourism development (Smith \& Duffy, 2003; Leksakundilok \& Hirsch, 2008; Suansri, 2013) and therefore any development can be better implemented and managed ( $\mathrm{Li}$, 2004; Rocharungsat, 2008).

Models of best practices have been drafted that are aimed at improving the way in which CBT can provide holistic community benefits (Mtapuri \& Giampiccoli, 2013, 2014), but their application remains case specific. Communities require clear guidelines on how to develop and successfully implement a tourism product and how to devise marketing and visitor management strategies, all of which cannot be achieved without the adequate set of skills (Stoeck1, 2008). Tourism as a service industry greatly benefits when host communities' show motivation and are prepared to meet visitors' needs, which in turn increases tourists' 
willingness to visit as a result of improved tourism products and services that are delivered by positively inclined and prepared staff (Rocharungsat, 2008).

Besides varying CBT practices, evidence suggest that also degrees of actual community participation vary, from communities actively involved in decision making, to limited involvement at later stages of the tourism development process, to only being perfunctory consulted (Johnson \& Wilson, 2000; Mitchell \& Eagles, 2010). The intervention of outsiders, such as IDAs and NGOs, providing funding or technical assistance to some communities and none to others has in some cases lead to new forms of social and economic division, including intra- and inter- community rivalry (Smith \& Duffy, 2003). Most importantly, this has often ignored existing stakeholders' power relations (Novelli 2016). In fact, the claim of working 'in partnership' with a beneficiary community, often leads to power inequalities and confusions in regards to responsibilities and the degrees of control and decision-making (Dolezal, 2015). Knowledgeable outsiders experience advantages over the local population when planning and making decisions, oftentimes leading community members to experience frustration and a feeling of not-being-heard by those with a better understanding of the sector (Reid et al., 2004), who oftentimes take decisions on their behalf. The power relationship divide is exacerbated by local communities form peripheral regions having very little or no experience in being a tourist or in handling tourism and visitors (Pearce, et al., 1996; Leksakundilok \& Hirsch, 2008). In addition, concealed power differences within a community, such as age, gender or belonging to a certain social group can influence participation and partnerships (Johnson \& Wilson, 2000), thus furthering power inequalities and increasing the risk of CBT resulting in poor performance and failure (Hall, 2005; Stoeckl, 2008). 
Over the past three decades, a number of initiatives to address afore mentioned challenges associated with CBT have taken place. For instance, the UN World Tourism Organisation (UNWTO) have a history of holding seminars, workshops and conferences specifically aimed at increasing awareness, providing education and support in the implementation of sustainable tourism practices (Rocharungsat, 2008). In addition, organisations, including IDAs and NGOs, have been providing skills training and education specifically related to the planning and development of local CBT groups, project management, tour guiding, marketing and monitoring of operations (Suansri, 2013; Suansri \& Richards, 2009). However, the general lack of a common understanding and inconsistent application of CBT makes any validation, benchmarking and monitoring of business practices extremely difficult (Smith \& Duffy, 2003). While CBT gained momentum as a reflection of the sustainable tourism development agenda (Smith \& Duffy, 2003; Leksakundilok \& Hirsch, 2008; Rocharungsat, 2008; WCED, 1987; Baker, Kousis, Richardson \& Young, 1997; Pridham \& Konstadakopulos, 1997; Weaver, 2006; Goessling, Hall \& Weaver., 2009), CBTS have emerged from STS as a tool to improve the CBT sector. However, their appropriateness, feasibility and effectiveness as a certification tool remain questionable.

\section{Tourism Industry Standards and Sustainability}

Tourism Industry Standards (TIS) are a documented set of rules, conditions and requirements, developed and published by a recognised body, which can either require the achievement of certain performance indicators or the implementation of specific management strategies. Applicants are assessed and verified according to those specific criteria and, if all requirements are met, certified with, for example, a specific label or award (Font, 2002a). One 
of the main aims of labelling and certification schemes is to encourage stakeholders to meet certain standards (Font, 2002b) and to ensure that both the market demand and supply sides understand and implement business best practices (Diamantis \& Westlake, 2001).

Where governments have imposed TIS, these have proved to have an influence on regulatory frameworks, such as: penal liability and legislation; facilitation and financing of technical assistance and funding applications; monitoring, verification and surveillance of correct practices in tourism (Font \& Bendell, 2002; Bendell \& Font, 2004). Historically, TIS focused on quality and health and safety issues, leaving sustainability out of the equation. Those that started addressing sustainability, mostly centred around environmental issues, such as water or waste management (Font \& Bendell, 2002; Bendell \& Font, 2004; Font \& Harris, 2004) and focused only years later on social issues such as corporate social-responsibility (Beckett \& Jonker, 2002; Font \& Harris, 2004; Strambach \& Surmeier, 2013; Landthaler, 2014). Although what followed was a greater emphasis on social issues (Griffin \& De Lacy, 2002; Font \& Harris, 2004), a focus on social aspects within TIS proved problematic, as it was open to subjective interpretations by auditors (Font \& Harris, 2004).

STS have gained importance as a consequence of increased public awareness about TIS, consumer rights and sustainability. They have become a benchmarking tool in business practices and a source of credibility and transparency for customers and tourism providers (Strambach \& Surmeier, 2013). Sustainability labels and eco-certificates help identifying tourism organisation, which respectively adopt sustainable tourism and eco-friendly practices (Font, 2001; Font \& Harris, 2004). They can contribute towards transparency and good governance, motivate stakeholders to adapt planning and monitoring approaches, support 
market confidence and access, improve product and service quality (Suansri \& Yeejaw-haw, 2013) and increase competitive advantage and corporate image (Jarvis, Weeden \& Simcock, 2010). During the last decade, while the drastic increase of voluntary standards has generally had a positive influence on industry performances (Font, 2002a; Font, 2002b; Bendell \& Font, 2004), the rapid proliferation of STS, including over 400 generic sustainability criteria (Landthaler, 2014) and 100 plus labelling programmes using the term 'eco', has resulted in diluted credibility, competitive advantage and practical significance, with many being used as a mere marketing tool (Self, et al, 2010; Francis \& Goodwin, 2009; Jarvis, et al., 2010), which is something to be considered when aspiring to develop and implement CBTS.

\subsection{The Global Sustainable Tourism Criteria}

An important step towards the development of STS was the introduction of the Global Sustainable Tourism Criteria (GSTC), which emerged in response to the United Nations' Millennium Goals (UNMDGs) with the aims of encouraging "effective sustainability planning, maximizing social and economic benefits for the local community, enhancing cultural heritage, and reducing [tourism's] negative impacts to the environment" (GSTC, 2013a, p. 1). GSTS serve as basic benchmarking for businesses to comply with and for consumers to identify and choose sustainable tourism products. They offer starting points for sustainable certificate development and act as guidelines for training and educational purposes (GSTC, 2013a). GSTC (2014) is an NGO, run on a voluntary basis and funded by donations, membership fees and sponsorships. GSTC addresses two main categories - 'hotels and tour operators' and 'destinations', which are assessed according to four thematic criteria, each sub-divided into indicators (Table 1). 
INSERT Table 1: Global Sustainable Tourism Criteria (Source: Adapted from GSTC, 2013a, 2013b)

\begin{abstract}
Although, at destination level, the criteria include a number of important indicators, such as monitoring, visitor satisfaction, safety, security and local career opportunities, aspects such as accommodation, local guides or boarding are missing. These are important for developing, monitoring and evaluating CBT performances, therefore restricting GSTC usefulness to CBT. GSTC have been criticised on a number of fronts, as a 'wish list' with insufficient and inflexible measurements, as an opaque certification process lacking of transparency with consumers not being able to give feedback or identify whether the criteria have actually been met in practice (Francis \& Goodwin, 2009). Furthermore, the implementation of GSTC is costly and their applicability to CBT remains limited due to community restricted financial resources, making them unable to meet the certification costs.
\end{abstract}

\title{
2.2 Green Globe 21
}

'Green Globe 21 is the global Affiliation, Benchmarking and Certification programme for sustainable travel and tourism' (Walker, 2008) and provides accreditation, training and education, as well as marketing services all over the world (Griffin \& De Lacy, 2002; Green Globe Certification, 2014a). It is perceived as the 'International Ecotourism Standard', having been established by Ecotourism Australia and the Cooperative Research Centre for Sustainable Tourism of Australia, based on Agenda 21 principles, the Australian Nature and Ecotourism Accreditation and GSTC (Green Globe Certification, 2014a). It has been developed with input from the private sector, communities and other tourism stakeholders 
(Green Globe Certification, 2014b), and includes four standards, which are each subdivided into indicators (table 2).

\begin{abstract}
INSERT Table 2: The Green Globe Certification Criteria (Green Globe Certification, 2014c)

Similarly to the GSTC, although the Green Globe 21 Criteria provides an overview of required business practices, it does not give any guidelines on how to achieve these, which is particularly needed for the development of CBT.
\end{abstract}

\title{
2.3 The Thai Community Based Tourism Standards and ASEAN
}

In the last two decades, in Southeast Asia, a number of NGOs have been involved in CBT and have delivered several capacity building and community development initiatives. However, in order to comply with growing tourist numbers, increased competiveness and market access, the need to improve product and service quality and sustainable practices has emerged, stimulating the demand for CBTS (Suansri \& Yeejaw-haw, 2013). In 2013, the Thai Community Based Tourism Institute (CBT-I) Standards were introduced, consisting of five criteria, each subdivided into indicators (table 3). The standards' main aim was to "clarify and protect community rights" (Suansri \& Yeejaw-haw, 2013, p. 7). Although, being accredited by an external organisation was seen as a source of pride for the community, which would result in increased credibility, improved market access and a boost in stakeholders' confidence in the sector (Suansri \& Yeejaw-haw, 2013), the CBT-I Standards remain a selfassessing, benchmarking and guiding tool, rather than a certification. 
INSERT Table 3: The Thai CBT-I Standards (Source: Adapted from Suansri and Yeejaw-haw, 2013)

The indicators are assessed in the form of a CBTS self-administered checklist with answers including 'yes', 'no' or 'not applicable', aimed at enabling the community to self-assess strengths, weaknesses and gaps in their CBT practice as well as identify areas which they wish to develop (Suansri \& Yeejaw-haw, 2013). However, since most communities develop CBT as a source of supplementary income, a main concern with the effectiveness of this CBTS is the availability of funds to support external audits. As a consequence, data may be manipulated during self-audits, which leads to the assessment process including questions with regard to transparency, truthfulness and reliability and, thus, legitimacy. Additionally, some of the indicators are vague and do not provide any measurable parameters. For example, when stated 'Homestay homes and activities use water efficiently' the word 'efficiently' is not accompanied by a definition, nor quantifiable parameters. Adding to the complexity are the different circumstances depending on the CBT context (Suansri \& Yeejaw-haw, 2013). For instance, a CBT project attracting tourists to Thailand's hill tribes may have very different environmental settings compared to a fishing community in the Philippines. As a consequence, indicators such as noise pollution, health and safety or accommodation arrangements will vary considerably. The CBT-I Standards therefore provide a comprehensive set of CBTS, but their specific geographical focus on Thailand restricts its relevance and applicability to other ASEAN destinations. A collaborative approach by ASEAN destinations to better understand and harmonise different CBTS' practices would be required to produce a cohesive set of ASEAN-CBTS, if at all possible. 


\section{Research Setting and Methodology}

\subsection{The Research Setting}

The Association of Southeast Asian Nations (ASEAN) was established in 1967, with Thailand, Malaysia, Indonesia, Singapore and the Philippines as founding members, later joined by Laos, Cambodia, Vietnam, Myanmar and Brunei (ASEAN, 2014a). The main aims and mandate of the association are: to accelerate economic growth and social development; to strengthen and promote peace and stability in the region and amongst all members; and to facilitate mutual assistance, collaboration and support in education, infrastructure, agriculture and other industries (ASEAN Secretariat, 2014b). Southeast Asia, with its unique and rich cultural and natural resources, has experienced rapid tourism growth (Son, Pigram \& Rugendyke, 1999; Rocharungsat, 2008), with sustainable development practices becoming recognised as being of great importance for the protection of ecosystems, the reduction of the negative impacts of mass tourism and the facilitation of sustainable economic benefits for local populations (Dolezal \& Trupp, 2015; Mitchell \& Eagles, 2010). Historically, the AsiaPacific region has been at the forefront in the development and implementation of sustainable tourism practices (Dowling, 2000; Leksakundilok \& Hirsch, 2008). This has largely resulted from the work of the Pacific Asia Travel Association (PATA), one of the first organisations to develop an environmental ethics programme and integrating sustainability in their code of conduct (Dowling, 2000; PATA, 2014). In the early 1990s, The International Tourism Society was one of the first organisations to establish ecotourism guidelines in Thailand, followed by the National Ecotourism Policy introduced by the Thai Government in 1997 (Dowling, 2000; Leksakundilok and Hirsch, 2008). Supported by the Thailand Research Fund (TRF), the CBTI is another example of a local NGO committed to "provide support and facilitate cooperation 
among stakeholders from grassroots communities to international levels, [and] strengthen the capacity of Thai communities to manage tourism sustainably" (Suansri \& Richards, 2009, p. 116). Since 2006, the CBT-I has been working tirelessly in collaboration with communities, the government, NGOs, academies and responsible tourism businesses by providing study tours, training workshops, consultancy and general support to key tourism stakeholders (Suansri \& Richards, 2009).

Despite evident good practice when it comes to CBT in Thailand, this has not been replicated across the ASEAN region. In some ASEAN destinations, sustainable tourism has experienced substantial implementation challenges particularly associated with the lack of infrastructures, skills and training facilities as well as political instability (Dowling, 2000), which has particularly affected the wider success of $\mathrm{CBT}$ in the region. However, given the increase in demand for CBT and some CBT successes in the region (Suansri, 2013), ASEAN decided that a set of standards was required for CBT to guarantee a consistent experience across its member states (ASEAN, 2014c).

\subsection{Methodology}

The overall aim of this research is to investigate the feasibility and appropriateness of the establishment of the ASEAN-CBTS. A qualitative research approach is most suitable, due to the complexity of the topic and the need to sieve through experiences, beliefs, attitudes and behaviour of those with an expert view of the CBT sector.

From an epistemological perspective, this research adopted a constructionist approach (Botterill \& Platenkamp, 2012). This was most adequate to assess the social phenomenon of 
CBT and reflect upon the appropriateness of implementing CBTS in the ASEAN based on the interpretation of ideas expressed by research participants. The research question derived from a critical review of the literature on sustainable development, CBT, its role in ASEAN and the evaluation of other TIS. Research respondents were selected on the basis of their specific knowledge and expertise, which emerged also though the scrutiny of literature on the topic. The qualitative assessment of their professional views (Smith, 2010; Botterill \& Platenkamp, 2012) about CBTS in general and in the context of the ASEAN in particular was assessed through the use of open-ended questions and a flexible approach in the questioning process, which included follow-up and probing questions, and a dialogue (in English) that provided detailed information. A list with questions and topics relevant to the research was used to guide the interviews, however there was no set order of questions, which generally followed the flow of the conversation and the interviewees' thinking process and reflections (Jennings, 2001). All interviews were tape-recorded and transcribed. Thematic areas were derived in relation to the research objectives (see table 4) and data was colour coded accordingly, helping with the identification of patterns.

INSERT Table 4: Research Objectives/Thematic areas vs. Secondary/Primary Research

Based on the researchers' familiarity with the sustainable tourism research community (Jennings, 2001), six key research participants were chosen for this study from a pool of international and local experts, on the basis of their involvement in CBT in ASEAN and/or their expertise in the field of STS and certification. Interviews took place between November 2014 and December 2014. Due to the limited availability of resources (time and budget) and the extended geographical area in which research participants were based, interviews were 
conducted via Skype (with video connection where possible), which emerged as sufficiently adequate in providing a personal rapport between researcher and interviewee (Smith, 2010).

\begin{abstract}
All participants were given written and verbal information about the research and the option to withdraw at any point. They accepted the invitation to be interviewed and gave informed verbal and recorded consent for the collection of data and recording of interviews. Furthermore, issues of confidentiality, anonymity and privacy were considered, with research participants being given the choice to remain anonymous. Although most had agreed to be named in the final output emerging from the research, respondents were coded (RP1 to RP6 table 5) to enable a consistent anonymous responses' format.
\end{abstract}

\title{
INSERT Table 5: Research Participants
}

Respondents were also chosen in order to generate a complete picture on the research from different perspectives, including CBT networks, industry experts and academics. In order to avoid misinterpretation and misunderstandings research participants' direct quotes were sent to participants for validation (Maxwell, 2005).

\section{Findings and Discussion}

\subsection{The ASEAN-CBTS}

One of the actions taken by the CBT-I to improve CBT was the CBTS handbook published in 2013, which includes a CBT-I Standards' checklist. Although this had been the result of grass-root level consultations with over 60 Thai communities (RP3), who generally bought into the idea of a CBTS, the Thai government had not yet endorsed them (Suansri and 
Yeejaw-haw, 2013). This, in turn, weakened the value and effectiveness of their implementation. The CBT-I Standards' main intention was to foster local capacity and, progressively enable communities to gain sufficient experience with the help of the selfassessment CBTS' process, and possibly impact on their CBT performance (Suansri and Yeejaw-haw, 2013). According to one of the interviewees, this self-assessment process can, however, lead to biased results, therefore collaborations between communities, private sector and NGOs was suggested as the only advisable way to better understand strengths and weaknesses within the host communities (RP2). The gap between 'real CBT and fake CBT' (RP6) and the need to improve CBT products and services remains a fundamental issue and this type of CBTS engagement was regarded as a "planning, capacity building and selfmonitoring tool" (Suansri \& Yeejaw-haw, 2013, p. 21), rather than a marketing one. As a learning tool (RP2, RP3, RP5), it has enabled communities to 'identify areas, where they have strengths and weaknesses, and then, depending on how much time and how many resources they have and what the availability of people to assist them is, they can prioritise improving specific areas' (RP3). Similarly, the ASEAN-CBTS is not ready to be a certification, if ever, but should rather be used as an on-going process to facilitate capacity building (RP1, RP2, RP3, RP6). It needs to consider the different environments and characteristics of the various destinations and their communities, so that the criteria can be adjusted to changing circumstances (Suansri \& Yeejaw-haw, 2013), with flexibility and variations playing a key role in their applicability in Thailand as much as in the rest of the ASEAN destinations (RP1, RP3, RP4, RP6).

In November 2002, all ASEAN members signed the ASEAN Tourism Agreement with the ultimate ambition to implement a network approach in the development of sustainable tourism 
practices in South East Asia (ASEAN, 2014a). One of the objectives explicitly addresses the development and implementation of STS. Since then, standards for green hotels, homestays, ecotourism, public restrooms, clean tourist cities and ultimately community-based tourism have been developed (ASEAN, 2014c), with the aim to enhance the quality of tourism services, facilities and human resources all over ASEAN. Between 2007 and 2009, the European Centre for Ecological and Agricultural Tourism (ECEAT) implemented a project called 'Communities in International Business, Common quality standards and marketing for Community Based Tourism Businesses in Asia' (ECEAT, n.d.). Supporting CBT networks in Indonesia, Mongolia and Cambodia, the aim was to develop a common set of industry standards, investigate and enhance the tourism supply-chain and promote CBT. Cambodia was chosen as the host country to implement the CBTS, based on funding from the EU AsiaInvest initiative, with the objective of promoting and supporting business cooperation between Europe and Asia (GFWW, 2006). Thereupon, CCBEN developed a set of CBTS and with support from the Cambodian government who unilaterally published them as the CBTS for ASEAN. However, these CBTS have not been endorsed by ASEAN nor officially adopted by any other destination.

The current ASEAN-CBTS consists of 8 criteria (table 6) subdivided into 23 sub-criteria, which consist of a total of 171 performance indicators, categorized as 'Minimum Requirements', 'Advanced Requirements' and 'Best Practice Requirements' (Carter, 2014). Communities can reach different levels of performance and achieve scores for all applicable requirements according to a self-assessment form. As an outcome of the evaluation, CBT operations can reach a 'Registration' (complies with $60 \%$ of the minimum requirements), 'Endorsement' (complies with $80 \%$ of the minimum and $60 \%$ of the advanced requirements) 
or 'Certification' (complies with $100 \%$ of the minimum and $80 \%$ of the advanced requirements) stage (RP3).

INSERT Table 6: ASEAN-CBTS Criteria (Source: Adapted from Carter, 2014).

The self-assessment has to be supported by evidence, such as reports, signed codes-ofconduct, photographic proof, data from observations and interviews with CBT groups, customers and tour operators. The communities are supported with standard handbooks, checklists, codes-of-conduct and community audit workbooks, with the main objective of identifying areas of improvement and enable identification of opportunities for strategic interventions and capacity building (Carter, 2014). The self-assessment was devised as a sustainable tourism planning tool, and is likely to remain the main if not the only achievable objective, given the diversity of those involved and the complex political environment (RP2, RP4, RP6).

\subsection{The Role of Key Stakeholders in CBTS}

\subsubsection{Governments}

The ASEAN 'Framework Agreement on Services' identifies tourism as one of the main sectors for "regional economic collaboration" (Wong, Mistilis \& Dwyer, 2011a, p. 885), with all ASEAN member states sharing an interest in promoting stability, predictability and reliability of the tourism industry within South East Asia. The involvement of governments in the development and implementation of the ASEAN-CBTS is strategically important (Font \& Bendell, 2002; Bendell \& Font, 2004). However, an evident disconnect exists between policy and implementation. While ASEAN tourism objectives fall under the general ASEAN 
economic cooperation framework, which means that tourism policies are defined at economic ministries' level, the implementation process remains in the hands of national tourism ministries. One of the main success factors for tourism development is the political will and support from governments and leaders and their role as advisors and coordinators (Wong et al., 2011). While national institutions (i.e. Ministries of Tourism) may represent the most appropriate 'home' for CBTS (RP2, RP4, RP5, RP6), and guarantee long term sustainability (RP6), in a region where numerous NGOs engage in project-based ventures with limited time and budgets, a main constraining factor in CBTS' implementation is the lack of governance continuity. For example, since the end of the project through which CCBEN and the Cambodian government drafted the ASEAN-CBTS, neither a follow-up nor a coordinated push for the endorsement and launch of the CBTS in ASEAN has taken place (RP5). Contrasting views on the ASEAN-CBTS governance model have therefore emerged. A number of participants viewed governments as 'facilitators best placed to establish an enabling environment in which CBTS can be introduced and implemented' (RP2), others regarded governments as mere 'host organisations' (RP6) or 'the entities responsible for the final evaluation' (RP5). The feasibility of the Thai CBT-I Standards model, whereby the government finances the homestay standard and employs external (third party) auditors (RP3) was generally dismissed as feasible option as a government-financed evaluation process across ASEAN would be unaffordable due to the widespread lack of funding that affects the tourism sector in the region (RP1).

In addition to the diverse regional cultural context, further challenges to the effective implementation of tourism policies exist. These include the lack of political, the recurrent change of governments, tourism ministers and NTOs, the generally slow public policy 
development and implementation process and the limited coordination and communication among government agencies (Wong et al., 2011b). This is even more so the case in the context of the ASEAN tourism industry, where policy development and implementation depends upon the collaboration of several government bodies, such as ministries of tourism, immigration, transportation, aviation, national parks, international trade and forestry departments (Wong et al, 2011b). The complex multi-stakeholder approach required, the lack of understanding of the needs of the tourism industry and the consequent disengaged approach of some institutions threaten the effective implementation of any tourism project, including the CBTS (RP2).

\subsubsection{Communities}

The involvement and participation of community grass-roots members in CBT are a welltraversed topic (Leksakundilok \& Hirsch, 2008; Rocharungsat, 2008). As one of the respondents states, 'when we're talking about Community Based Tourism, of course, it's absolutely fundamental that communities are involved in the development of the standards' (RP3). Community consultations are a critical component in the success of CBTS, as they need to reflect communities' perspective, needs and wishes (RP4). However, the inconsistent and often incompressible set of information by organisations providing technical assistance has often created confusion about the standards, their implementation and evaluation (RP1, RP6). This highlights the need for a coordinated action (RP6) and clear guidelines on the CBTS' process for inclusion (RP4), otherwise there is the potential of misunderstandings leading to conflict (Reid, et al., 2004; Stoeckl, 2008). Most 'standards are very top-down' and take little notice of local CBT organisations and the actual end-users' views (RP1). Evidence of consultations taking place with already well-developed CBT organisation, rather than those 
requiring improvement of their practice, has often led to potential misjudgement of the real needs on the ground (RP1). In Indonesia for example, standards developed by outside consultants and government officials resulted in inconsistent recommendations that are completely disassociated with local realities and characterised by a misrepresentation of local community views and needs (RP4). This, in turn, widens the implementation gap and poses questions over the appropriateness of such practices.

\subsubsection{Other Stakeholders}

The multi-stakeholder approach adopted by CBT-I, CCBEN and INDECON can be seen as a model of good practice. The approach includes governments, civil societies, communities, the private sector and tourists involved in the planning and development of the various CBTS, feeding into the ASEAN-CBTS. Nevertheless, the implementation of a cohesive and unified ASEAN-CBTS remains challenged by different practices widely used in each country. For instance, whereas INDECON's CBT checklist is used merely in Indonesia (RP4), the CBT-I Standards are applied in Thailand only (RP6). The literature has evidenced how NGOs have supported CBT (Ko, 2001; Rocharungsat, 2008) and respondents noted how NGO's have provided training and skills development initiatives (RP1, RP2, RP6). However, a bettercoordinated and collaborative approach between those operating in the region (i.e. while DASTA is using the ASEAN-CBTS, CBT-I uses its own criteria) is needed to harmonise CBTS' practices and implement the ASEAN-CBTS more cohesively and widely (RP6).

In addition to this, given the role of the private sector (i.e. tour operators, tourism associations and travel agents) and tourists in the success of CBT (RP1), as they participate in the development, implementation and consumption of it, their active engagement in the 
evaluation stage of CBTS was suggested as an option (RP6). Notwithstanding, that the lack of knowledge about their target market can result in misunderstandings and tourists' negative experiences of the CBT product (Pearce, et al., 1996; Hall, 2005; Leksakundilok \& Hirsch, 2008; Stoeckl, 2008), what is often ignored is that local communities do not intuitionally understand tourists' needs, requirements and expectations, having no or very limited experience about the sector. The situation is similar in terms of communities' understanding of CBTS, which needs to be firstly mapped against a fully understood CBT product offering and then implemented as part of a clearly communicated collaborative strategy between key stakeholders (RP3).

Within ASEAN, tourism policies are developed and adopted with a pragmatic, necessitydriven approach, but a lack of "industry-specific procedural rules as well as monitoring and enforcement mechanisms" (Wong et al., 2011a, p. 894) weakens their effective implementation. In principle, the registration and endorsement of the ASEAN-CBTS is a process in the hands of CBT administering authorities, whereas the certification is meant to be undertaken by a national tourism organisation (Carter, 2014). However, reservations about stakeholders' roles and responsibilities about each stage of the ASEAN-CBTS emerged (RP3, RP5), in particular in relation to who should deal with the evaluation and monitoring process and defray the costs of CBTS (RP2). 


\subsection{ASEAN-CBTS: Challenges, Opportunities and Operational Issues}

\subsubsection{Challenges}

As previously mentioned, funding constitutes a major limitation to the general development of tourism in ASEAN destinations and the implementation of a common CBTS. ASEAN tourism is mainly funded by the member states and is based on an equal contribution principle, which means that all member states are supposed to contribute the same amount of money for ASEAN tourism projects and activities (Wong et al., 2011b). However, in reality, the amount of contribution is calculated according to the amount that less-developed countries are able or willing to contribute. Even though government, with support from IDAs, may have disbursed funds in the planning phase of the ASEAN-CBTS, many countries within ASEAN appeared to have limited their funding or even withdrawn their financial support in the implementation phase (RP5).

The lack of sufficient financial resources presents a major hindering factor in the implementation of tourism projects and policies (Wong, et al., 2011b; Suansri \& Yeejaw-haw, 2013), with CBT generally depending on financial support from outside donor organisations, (RP3). As CBTS depends upon three stages - development, implementation and evaluation, in order to be effective, adequate funding is required for each phase. Organisations, such as ECEAT, or tourism associations and IDAs have indeed played a fundamental role in funding the development stage of the ASEAN-CBTS (RP6), but, according to respondents RP4 and RP5, national governments should take responsibility for funding its implementation stage. Self-assessment forms represent an inexpensive method to implement the ASEAN-CBTS' evaluation stage, by being in the hands of each CBT operator, eventually seeking an external certification, if they wish to do so. Non-direct business-to-business financing schemes would 
be the most appropriate and most transparent way to evaluate and monitor CBTS within ASEAN (RP2). However, some rejected the proposition of a business-to-business approach, as in the case of relatively poor communities 'the increased cost of capacity building, plus then quality insurance to meet those standards will by far exceed the increased revenue CBT are going to get' (RP1). The view that a 'non business-to-business CBTS approach' may further perpetuate a donors' dependency cycle may be strengthened by the fact that those CBT projects that are unable to finance the evaluation of their own operation due to limited profitability may not only limit the full implementation CBTS within their operation, but may raise fundamental questions about their long-term sustainability.

What is more is that the political culture within ASEAN follows consensus-seeking and allequal principles, impacting upon the success of tourism collaboration and the effective implementation of any CBTS (Wong et al., 2011a). Such principle can constrain the success of certain projects by simply requiring that benefits be generated for all ASEAN members (Wong et al., 2011a). However, within ASEAN, member states vary in size, economic power and stages of economic development, so an equal collaboration and progress in tourism development is in itself difficult if not impossible. Such differences are known to potentially create social-economic division, which in turn may negatively affect collaboration (Johnson \& Wilson, 2000; Smith \& Duffy, 2003; Reid, et al., 2004). Thailand and Indonesia, for example, are evidently more experienced and more advanced in the development of CBT products, whereas Laos, Myanmar or Vietnam remain relatively new to the concept (RP4). Such differences pose fundamental operational challenges in the way CBTS should be implemented as 'if you use a low benchmark, then it will be a downgrading for the Thailand users. But if you put a very, very high standard, then it will be very difficult for our friends in, 
for example, Laos to catch up' (RP4). Each country and each village within ASEAN shows great differences in terms of landscape, culture, development progress and environment and as one of the respondents put it, 'I cannot imagine how to impose one common standard within Indonesia, let alone for ASEAN' (RP4). While such diversity between different countries and communities can get lost with the introduction of one common CBTS (RP1, RP2, RP4), by 'tak[ing] authenticity and uniqueness away' (RP2), tourists are looking for seamless experiences as “[t]hey want a localised experience, but in a globalised world.' (RP1). They wish to experience products and services which are comparable in terms of quality (RP4), without taking away from the unique character of the location in which they are offered. This does not mean that 'you can't have a bamboo house, it just says your roof on your bamboo house shouldn't leak' (RP3).

\subsubsection{Opportunities and Operational Issues}

Notwithstanding the recognised challenges associated with the implementation of the ASEAN-CBTS, the support that they can provide to communities in dealing with the growing CBT demand is obvious. It is suggested that, as a planning rather than a certification tool, ASEAN-CBTS will impact positively on improving CBT in the region, by identifying strengths and weaknesses of CBT communities (RP3), by facilitating ad-hoc capacity building initiatives as well as by sharing good practices amongst ASEAN destinations (RP1, RP3). Communities would become stronger and better organised, which will prevent them from being exploited by tour operators and visitors (RP2). ASEAN-CBTS could also be used as a tool to improve management skills and introduce sustainable management systems (RP3, RP5, RP6). The aspect of management is in fact the very first performance criterion of the ASEAN-CBTS (Carter, 2014). Given that the actual effect of standards on securing better 
market shares is not guaranteed (Francis \& Goodwin, 2009; Jarvis, et al., 2010), ASEANCBTS would work as a 'partnership tool', facilitating collaborations, for example between CBT and tour operators, indirectly tapping on marketing opportunities (RP3) offered by a better understood visitors' market. The ASEAN-CBTS would eventually create more trust between tour operators, tourists and communities by providing certainty and clarity about the CBT product, its appeal and impacts (RP4).

Contemporary tourists place much importance and trust in word-of-mouth reviews and platforms, such as TripAdvisor, rather than official tourism standards and accreditations:

We are moving towards a system, where authority based systems are not really trusted by customers anymore. They are not particularly market relevant or flexible. (RP1)

Therefore, the opinion of past visitors may become far more crucial than that of a certification process, having a considerable value in marketing and promotion terms. By simply being enabled to better understand, plan, manage and deliver their CBT offering, communities would improve their operations, positively influence tourists' perceptions and experiences and potentially attract more customers (RP2, RP3, RP4, RP6).

Throughout the research, it became clear that the introduction of an external evaluation system was premature. Hence, a feedback system whereby communities, tour operators and tourists could share opinions about requirements and experiences could potentially assist in generating a transparent evaluation (RP1) of 'what really happens in CBT' (RP2), rather than imposing pre-constituted parameters, which may not be achievable. It was suggested that, simple minimum standards or common principles may help set a clearer list of achievable 
parameters for communities to be guided through the process of standardisation (RP3, RP4). Instead of only focusing just on services and quality of products, the ASEAN-CBTS needed to address sustainable management practices, cultural and environmental benefits and the fair distribution of income (RP6) as fundamental characteristics of the sustainable tourism business model. CBTS must become embedded within CBT practices at national level first, with minimum parameters helping CBT improve and develop further (RP3) rather than being a top down imposed one. Evidence from Thailand, Indonesia and Cambodia suggests that working at national level first is the most appropriate way forward (RP2, RP3, RP4, RP5, RP6). An advanced ASEAN-CBTS could be an option for the future (RP3), and although most respondents agreed in principle that ASEAN-CBTS is necessary as a planning tool, it is yet premature to assume that it would work in such a complex socio-economic setting.

\section{Conclusions}

This paper has explored the appropriateness of the ASEAN-CBTS certification and more specifically key challenges and opportunities associated with its implementation. Framed by a critical overview of CBT and CBTS, the paper discussed how ASEAN's aspirations of leveraging the ASEAN-CBTS as a planning tool to support and promote sustainable forms of CBT in the region is challenged by the complexities of a multifaceted political situation, diverse cultural settings, weak institutions and governance in areas such as tourism planning, human resources, capacity and funding.

Yet, despite these challenges, it was suggested that a collaborative multi-stakeholders' approach harmonising national CBTS practices would accelerate the implementation of the ASEAN-CBTS in the region. In fact, as evidenced in the case of CBT-I, CCBEN and 
INDECON a multi-stakeholder approach in the planning and implementation of national CBTS worked with the self-assessment process providing a good starting point to evaluate CBT strengths and weaknesses and serving as an effective planning tool. Although, CBT generally remains dependent upon IDAs and NGOs' financial and technical support, in order for CBT to become a self-reliant and sustainable sector, a collaborative business model would be useful. This would mean that CBTS are endorsed by national governments and embedded in local business practices to become firmly established as a good practice in the tourism industry.

Slow political process, fast shifting governing bodied and limited funding have hindered the effective implementation of the CBTS and weakened collaboration prospects and effective communication between the various CBTS-ASEAN actors (i.e. political bodies, private sector operators, IDAs and civil societies). While the ASEAN-CBTS development stage had been widely supported by IDAs and NGOs, it was suggested that the implementation stage should be in the hands of national government, with the private sector taking responsibility for the evaluation component stage.

The proposed staged implementation of the ASEAN-CBTS and a self-assessed minimum standards' approach, whereby all must comply with a set of minimum requirements was indeed useful, as communities in ASEAN could use a building-block approach in the gradual achievement of key CBTS and, once they are ready, move to the next levels (i.e. 'advanced' and 'best practice'). However, the facilitation of basic entrepreneurial, leadership and sectorspecific technical capacity-building activities remain fundamental if communities are to shift 
from a development project mentality and aid dependent practice to a profitable business one, which is needed to deliver a competitive CBT product.

The ASEAN-CBTS represent an extremely useful and necessary tool to build communities' capacity and improve CBT products, services and management practices. However, the necessity of implementing CBTS at national level is a fundamental step that can no longer be ignored. It is likely to take some time before the ASEAN-CBTS will achieve its aspiration of becoming a fully implemented transnational certification programme - and we do not yet know whether this will ever be possible at all. Nevertheless, shifting ASEAN-CBTS' core focus from an aspirational to the pragmatic approach as a planning and development tool rather than an evaluating one is both realistic and useful, given the complexity of CBT in general and the geographical setting in which the ASEAN-CBTS is meant to operate.

If CBTS are to contribute to the sustainable growth of CBT and ultimately to the socioeconomic wellbeing of remote rural areas, they will need to emerge from a harmonized set of CBT guidelines, which, at the same time, acknowledge local differences. The appropriateness and feasibility of CBTS remain an under researched topic and yet, in addition to holding much potential, remain susceptible to the risks of a 'one fits' all measure. It becomes increasingly obvious that CBTS emerge out of the need to address wider problems such as the lack of understanding of CBT's complexity and the growing desire to address rural poverty through CBT increasingly challenged by the unsustainable nature of certain CBT practices. Tackling these issues first through creating a more widespread understanding of CBT competitiveness and service delivery therefore needs to be the utmost priority before engaging in cross-country CBT benchmarking, standardization and certification. 


\section{References}

Aref, F. (2011). Barriers to community capacity building for tourism development in communities in Shiraz, Iran. Journal of Sustainable Tourism, 19(3), 347-359.

ASEAN (2014). Overview. Retrieved from http://www.asean.org/asean/about-asean

ASEAN Secretariat (2014a). ASEAN tourism agreement. Retrieved from http://www.asean.org/news/item/asean-tourism-agreement

ASEAN Secretariat (2014b). ASEAN tourism ministers meeting (M-ATM). Retrieved from http://www.asean.org/communities/asean-economic-community/category/asean-tourismministers-meeting-m-atm

Baker, S., Kousis, M., Richardson, D., \& Young, S. (1997). Introduction: The theory and practice of sustainable development in EU perspective. In S. Baker, M. Kousis, D. Richardson, \& S. Young (Eds.), The politics of sustainable development (pp. 1-42). London: Routledge.

Beckett, R., \& Jonker, J. (2002). AccountAbility 1000: A new social standard for building sustainability. Managerial Auditing Journal, 17(5), 36-42.

Bendell, J., \& Font, X. (2004). Which tourism rules? Green standards and GATS. Annals of Tourism Research, 31(1), 139-156.

Botterill, D., \& Platenkamp, V. (2012). Key concepts in tourism research. London: Sage.

Carter, B. (2014). International conference on community development through tourism [Power Point presentation]. Retrieved from http://sustain.pata.org/wpcontent/uploads/2014/09/RW-Bill-Carter-ASEAN-CBT-Standard.pdf

Diamantis, D., \& Westlake, J. (2001). Ecolabeling in the context of sustainable tourism and ecotourism. In X. Font, \& R. C. Buckley (Eds.), Tourism ecolabelling: Certification and promotion of sustainable management (pp. 27-40). Wallingford: CABI.

Dolezal, C. (2015a). Questioning empowerment in community-based tourism in rural Bali. (Unpublished doctoral dissertation). University of Brighton, UK.

Dolezal, C. (2015b). The tourism encounter in community-based tourism in Northern Thailand: Empty meeting ground or space for change? ASEAS - Austrian Journal of SouthEast Asian Studies, 8(2), 165-186.

Dolezal, C., \& Trupp, A. (2015). Tourism and development in Southeast Asia. ASEAS Austrian Journal of South-East Asian Studies, 8(2), 117-124.

Dowling, R. K. (2000). Ecotourism in Southeast Asia: A golden opportunity for local communities. In K. S. Chon (Ed.), Tourism in Southeast Asia: A new direction (pp. 1-20). Binghamton: The Haworth Press.

ECEAT (n.d.). Promotion of sustainable tourism products. Retrieved from http://www.eceatprojects.org/html/promotion.html 
Erskine, L.M., \& Meyer, D. (2012). Influenced and influential: the role of tour operators and development organisations in tourism and poverty reduction in Ecuador. Journal of Sustainable Tourism, 20(3), 339-357

Font, X. (2001). Regulating the green message: The players in ecolabelling. In X. Font, \& R. C. Buckley (Eds.), Tourism ecolabelling: Certification and promotion of sustainable management (pp. 1-17). Wallingford: CABI.

Font, X. (2002a). Environmental certification in tourism and hospitality: Progress, process and prospects. Tourism Management, 23(3), 197-205.

Font, X. (2002b). Certification systems and standards in tourism. Annals of Tourism Research, 29(3), 869-870.

Font, X., \& Bendell, J. (2002). Standards for sustainable tourism for the purpose of multilateral trade negotiations. Leeds: WTO.

Font, X., \& Harris, C. (2004). Rethinking standards from green to sustainable. Annals of Tourism Research, 31(4), 986-1007.

Francis, J., \& Goodwin, H. (2009). Open letter and petition on the Global Sustainable Tourism Criteria. Retrieved from http://www.responsibletravel.com/copy/open-letter-andpetition-on-the-global-sustainable-tourism-criteria

GFWW. (2006). Welcome on pages of the Asia Invest Project SELECT-IT. Retrieved from http://www.asia-invest.de/select-it/index.html

Goessling, S., Hall, M. C., \& Weaver, D. B. (2009). Sustainable tourism futures: Perspectives on systems, restructuring and innovations. In S. Goessling, M. C. Hall, \& D. B. Weaver (Eds.), Sustainable Tourism Futures (pp. 1-18). New York: Routledge.

Goodwin, H., \& Santilli, R. (2009). Community-based tourism: A success? ICRT Occasional Paper No. 11. International Centre for Responsible Tourism. Retrieved from http://www.haroldgoodwin.info/uploads/CBTaSuccessPubpdf.pdf

Green Globe Certification (2014a). Green Globe Certification. Retrieved from http://greenglobe.com/about/

Green Globe Certification (2014b). About Green Globe. Retrieved from http://greenglobe.com/about/

Green Globe Certification (2014c). Standard Criteria and Indicators. Retrieved from http://greenglobe.com/standard/

Griffin, T., \& De Lacy, T. (2002). Green Globe: Sustainability accreditation for tourism. In P. Williams, T. Griffin, \& R. Harris (Eds.), Sustainable tourism: A global perspective (pp. 5888). Oxford: Butterworth-Heinemann.

GSTC. (2013a). Global sustainable tourism council criteria and suggested performance indicators for hotels and tour operators. Retrieved from http://www.gstcouncil.org/images/pdf/HTO-CRITERIA_and_INDICATORS_6-9-14.pdf 
GSTC. (2013b). Global sustainable tourism council criteria and suggested performance indicators for destinations. Retrieved from http://www.gstcouncil.org/images/Dest_CRITERIA_and_INDICATORS_6-9-14.pdf

GSTC. (2014). Welcome to sustainable tourism. Retrieved from http://www.gstcouncil.org/about/learn-about-gstc.html

Hall, C. M. (2005). Tourism: Rethinking the social science of mobility. Harlow: Pearson.

Jarvis, N., Weeden, C., \& Simcock, N. (2010). The benefits and challenges of sustainable tourism certification: A case study of the Green Tourism Scheme in the west of England. Journal of Hospitality and Tourism Management, 17(1), 83-93.

Jennings, G. (2001). Tourism research. Milton: John Wiley \& Sons Australia.

Johnson, H., \& Wilson, G. (2000). Biting the bullet: Civil society, social learning and the transformation of local governance. World Development, 28(11), 1891-1906.

Ko, J. T. (2001). Assessing progress of tourism sustainability. Annals of Tourism Research, 28(3), 817-820.

Landthaler, M. (2014). Fostering sustainability in tourism. International Trade Forum, 1(1), 34-35.

Le, T-A., Weaver, D., \& Lawton, L. (2012). 'Factors influencing the performance of community- based tourism in the semi-periphery of Vietnam: A resident perspective from Ta Van Village'. The new golden age of tourism and hospitality CAUTHE, Council for Australian University Tourism and Hospitality Education, Melbourne Convention and Exhibition Centre, Proceedings Book 2: 361-365.

Leksakundilok, A., \& Hirsch, P. (2008). Community-based ecotourism in Thailand. In J. Connell, \& B. Rugendyke (Eds.), Tourism at the grassroots: Villagers and visitors in the Asia-Pacific (pp. 214-235). Abingdon: Routledge.

Li, Y. (2004). Exploring community tourism in China: The case of Nanshan Cultural Tourism Zone. Journal of Sustainable Tourism, 12(3), 175-193.

Maxwell, J. A. (2005). Qualitative research design: An interactive approach (2nd ed.). London: Sage.

Mitchell, R. E., \& Eagles, P. F. (2010). An integrative approach to tourism: Lessons from the Andes in Peru. Journal of Sustainable Tourism, 9(1), 4-28.

Moscardo, G. (2008). Community capacity building: An emerging challenge for tourism development. In G. Moscardo (Ed.), Building community capacity for tourism development (pp. 1-15). Wallingford: CABI.

Murphy, P.E. (1983). Tourism as a community industry: An ecological model of tourism development. Tourism Management, 4(3), 180-193.

Murphy, P.E. (1985). Tourism: A community approach. New York: Methuen. 
Murphy, P.E. (1988). Community driven tourism planning, Tourism Management, 9(2), 96104.

Mtapuri, O., \& Giampiccoli, A. (2014). Towards a comprehensive model of communitybased tourism development. South African Geographical Journal, 98(1), 154-168.

Mtapuri, O., \& Giampiccoli, A. (2013). Interrogating the role of the state and non-state actors in community-based tourism ventures: Toward a model for spreading the benefits. South African Geographical Journal, 95(1), 1-15.

Novelli, M. (2016). Tourism and development in Sub-Saharan Africa: Contemporary issues and local realities. Oxford: Routledge.

Novelli, M., \& Gebhardt, K. (2007). Community based tourism in Namibia: 'Reality show' or 'window dressing'? Current Issues in Tourism, 10(5), 1-37.

PATA. (2014). About PATA sustainability \& social responsibility. Retrieved from http://sustain.pata.org/about/about-pata-sustainability-social-responsibility/

Pearce, P. L., Moscardo, G., \& Ross, G. F. (1996). Tourism community relationships. Oxford: Pergamon Press.

Pridham, G., \& Konstadakopulos, D. (1997). Sustainable development in Mediterranean Europe? Interactions between European, national and sub-national levels. In S. Baker, M. Kousis, D. Richardson, \& S. Young (Eds.), The Politics of Sustainable Development (pp. 127151). London: Routledge.

Reid, D. G., Mair, H., \& George, W. (2004). Community tourism planning: A self-assessment instrument. Annals of Tourism Research, 31(3), 623-639.

Rocharungsat, P. (2008). Community-based tourism in Asia. In G. Moscardo (Ed.), Building Community Capacity for Tourism Development (pp. 60-74). Wallingford: CABI.

Scheyvens, R. (2002). Tourism for development empowering community. Harlow: Prentice Hall.

Self, R. M., Self, D. R., \& Bell-Haynes, J. (2010). Marketing tourism in the Galapagos Islands: Ecotourism or greenwashing? International Business and Economics Research Journal, 9(6), 111-125.

Smith, M., \& Duffy, R. (2003). The ethics of tourism development. London: Routledge.

Smith, S. L. (2010). Practical tourism research. Wallingford: Cabi.

Snyman, S. (2012a). Ecotourism joint ventures between the private sector and communities: An updated analysis of the Torra Conservancy and Damaraland Camp partnership, Namibia. Tourism Management Perspectives, 4, 127-135.

Snyman, S. (2012b). The role of ecotourism employment in poverty reduction and community perceptions of conservation and tourism in southern Africa. Journal of Sustainable Tourism, 20(3), 395-416. 
Son, N. T., Pigram, J. J., \& Rugendyke, B. A. (1999). Tourism development and national parks in developing world: Cat Ba Island National Park, Vietnam. In G. P. Douglas, \& R. W. Butler (Eds.), Contemporary Issues in Tourism Development (pp. 211-231). London: Routledge.

Stoeckl, N. (2008). Enhancing the economic benefits of tourism at the local level. In G. Moscardo (Ed.), Building Community Capacity for Tourism Development (pp. 16-28). Wallingford: CABI.

Strambach, S., \& Surmeier, A. (2013). Knowledge dynamics in setting sustainable standards in tourism - the case of 'Fair Trade in Tourism South Africa'. Current Issues in Tourism, 16(7-8), 736-752.

Suansri, P. (2013). Introduction. In J. Hummel, H. de Jong, \& K. Dhiradityakul (Eds.), Innovating CBT in ASEAN: Current directions and new horizons (pp. 1-4). Chiang Mai: CBT-I.

Suansri, P., \& Richards, P. (2009). Local Insight: Thai community based tourism. Chiang Mai: The Tourism Authority of Thailand.

Suansri, P., \& Yeejaw-haw, S. (2013). CBT standard handbook. Chiang Mai: CBT-I.

Walker, J., Mitchell, B., \& Wismer, S. (2001). Livelihood strategy approach to communitybased planning and assessment: A case study of Molas, Indonesia. Impact Assessment and Project Appraisal, 19(4), 297-309.

Walker, K. (2008). Linking a sense of place with a sense of care: Overcoming sustainability challenges faced by remote island communities. In G. Moscardo (Ed.), Building community capacity for tourism Development (pp. 41-59). Wallingford: CABI.

WCED. (1987). Our common future: Report of the World Commission on Environment and Development. Oxford: Oxford University Press.

Wearing, S., \& McDonald, M. (2002). The development of community-based tourism: Rethinking the relationship between tour operators and development agents as intermediaries in rural and isolated area communities. Journal of Sustainable Tourism, 10 (3), 191-206.

Weaver, D. (2006). Sustainable tourism: Theory and practice. Oxford: Elsevier ButterworthHeinemann.

Wong, E. P., Mistilis, N., \& Dwyer, L. (2011a). A model of ASEAN collaboration in tourism. Annals of Tourism Research, 38 (3), 882-899.

Wong, E. P., Mistilis, N., \& Dwyer, L. (2011b). A framework for analyzing intergovernmental collaboration: The case of ASEAN tourism. Tourism Management, 32, 367-376. 
Table 1: Global Sustainable Tourism Criteria (Source: Adapted from GSTC, 2013a, 2013b)

\begin{tabular}{|c|c|}
\hline \multicolumn{2}{|r|}{ Hotels and tour operators } \\
\hline Section A: & Demonstrate effective sustainable management \\
\hline Section B: & $\begin{array}{l}\text { Maximise social and economic benefits to the local community and minimise } \\
\text { negative impacts }\end{array}$ \\
\hline Section C: & Maximise benefits to cultural heritage and minimise negative impacts \\
\hline Section D: & Maximise benefits to the environment and minimise negative impacts \\
\hline \multicolumn{2}{|r|}{ Destinations (GSTC, 2013b) } \\
\hline Section A: & Demonstrate sustainable destination management \\
\hline Section B: & $\begin{array}{l}\text { Maximize social and economic benefits for the host community and } \\
\text { minimize negative impacts }\end{array}$ \\
\hline Section C: & $\begin{array}{l}\text { Maximize benefits to communities, visitors and cultural heritage and } \\
\text { minimize negative impacts }\end{array}$ \\
\hline Section D: & Maximize benefits to the environment and minimize negative impacts \\
\hline
\end{tabular}


Table 2: The Green Globe Certification Criteria (Green Globe Certification, 2014c)

\begin{tabular}{|l|l|}
\hline \multicolumn{1}{|c|}{ Criteria } & Indicators \\
\hline A. Sustainable Management & A.1 Implement a Sustainable Management System \\
& A.2 Legal Compliance \\
& A.3 Employee Training \\
& A.4 Customer Satisfaction \\
& A.5 Accuracy of Promotional Materials \\
& A.6 Local Zoning, Design and Construction \\
& A.7 Interpretation \\
& A.8 Communications Strategy \\
& A.9 Health and Safety \\
\hline B. Social/Economic & B.1 Community Development \\
& B.2 Local Employment \\
& B.3 Fair Trade \\
& B.4 Support Local Entrepreneurs \\
& B.5 Respect Local Communities \\
& B.6 Exploitation \\
& B.7 Equitable Hiring \\
& B.8 Employee Protection \\
& B.9 Basic Services \\
\hline D. Environmental & C.1 Code of Behavior \\
& C.2 Historical Artifacts \\
C.3 Protection of Sites \\
C.4 Incorporation of Culture
\end{tabular}


Table 3: The Thai CBT-I Standards (Source: Adapted from Suansri and Yeejaw-haw, 2013)

\begin{tabular}{|l|}
\hline Criteria \\
\hline i. Sustainable Tourism Management for Community Based Tourism \\
\hline ii. CBT distributes benefits broadly to the local area and society and improves quality of life \\
\hline iii. CBT celebrates, conserves and supports cultural heritage \\
\hline iv. Systematic, sustainable natural resource and environmental management \\
\hline v. CBT service and safety \\
\hline
\end{tabular}


Table 4: Research Objectives/Thematic areas vs. Secondary/Primary Research

\begin{tabular}{|c|c|c|c|}
\hline Research Objective & Relevant Literature & Primary Research & Interview Question \\
\hline $\begin{array}{l}\text { CBT development in } \\
\text { ASEAN and the CBT } \\
\text { Standard Draft }\end{array}$ & $\begin{array}{l}\text { Principles of } \\
\text { sustainable tourism. } \\
\text { CBT as growing } \\
\text { market in ASEAN. } \\
\text { Lack of academic lit. } \\
\text { on CBT standards }\end{array}$ & $\begin{array}{c}\text { CBT standard } \\
\text { implemented, not } \\
\text { officially endorsed. } \\
\text { Community } \\
\text { involvement. Capacity } \\
\text { building and self- } \\
\text { monitoring tool. }\end{array}$ & $\begin{array}{l}\text { Are the communities } \\
\text { in Thailand already } \\
\text { working with the CBT } \\
\text { standard? }\end{array}$ \\
\hline $\begin{array}{c}\text { CBT standard } \\
\text { development in } \\
\text { ASEAN }\end{array}$ & $\begin{array}{l}\text { ASEAN collaboration } \\
\text { in tourism. Standard } \\
\text { funded by ECEAT. } \\
\text { CBT principles. } 8 \\
\text { criteria groups }\end{array}$ & $\begin{array}{c}\text { CBT standard } \\
\text { developed, not yet } \\
\text { endorsed. Collaboration } \\
\text { CCBEN, Cambodia and } \\
\text { ASEAN }\end{array}$ & $\begin{array}{l}\text { Is there a common } \\
\text { CBT understanding } \\
\text { within ASEAN? } \\
\text { Are the communities } \\
\text { already working with a } \\
\text { standard? }\end{array}$ \\
\hline Stakeholders & $\begin{array}{c}\text { Political collaboration } \\
\text { within ASEAN. } \\
\text { Government } \\
\text { involvement advisable. } \\
\text { Community } \\
\text { involvement } \\
\text { necessary. NGOs }\end{array}$ & $\begin{array}{l}\text { Government as main } \\
\text { stakeholder. Stakeholder } \\
\text { mix: government, } \\
\text { communities, private } \\
\text { sector, tourists. } \\
\text { Challenges }\end{array}$ & $\begin{array}{l}\text { Who are the main } \\
\text { stakeholders when } \\
\text { developing/ } \\
\text { implementing/ } \\
\text { evaluating a CBT } \\
\text { standard? } \\
\text { Involvement of the } \\
\text { government? }\end{array}$ \\
\hline Challenges & $\begin{array}{l}\text { Funding. Political } \\
\text { culture. Impact on } \\
\text { marketing value not } \\
\text { proven. }\end{array}$ & $\begin{array}{l}\text { Funding. Stages of } \\
\text { development. } \\
\text { Standardisation. Impact } \\
\text { on marketing value? }\end{array}$ & $\begin{array}{l}\text { What are the main } \\
\text { limitations when } \\
\text { developing/ } \\
\text { implementing/ } \\
\text { evaluating CBT } \\
\text { standard? }\end{array}$ \\
\hline Benefits & $\begin{array}{l}\text { Identifying strengths, } \\
\text { weaknesses, gaps. }\end{array}$ & $\begin{array}{l}\text { Identifying strengths, } \\
\text { weaknesses, gaps. } \\
\text { Discussion between } \\
\text { communities and private } \\
\text { sector. Community } \\
\text { becomes organised and } \\
\text { strong. Quality of CBT } \\
\text { products }\end{array}$ & $\begin{array}{l}\text { What are the main } \\
\text { benefits? } \\
\text { Beneficiaries? }\end{array}$ \\
\hline $\begin{array}{l}\text { Potential Form, } \\
\text { Elements and } \\
\text { Aspects }\end{array}$ & $\begin{array}{l}\text { Self-assessment. } \\
\text { Outside evaluation } \\
\text { advisable. }\end{array}$ & $\begin{array}{l}\text { Capacity building and } \\
\text { management } \\
\text { improvement tool. Self- } \\
\text { assessment form. } \\
\text { Minimum standard. }\end{array}$ & $\begin{array}{c}\text { Self-assessment form } \\
\text { or outside evaluation? } \\
\text { Financing? } \\
\text { Main areas/issues? }\end{array}$ \\
\hline
\end{tabular}


Table 5: Research Participants

\begin{tabular}{|c|c|c|}
\hline Respondent & Position Respondent & $\begin{array}{c}\text { Interview length } \\
\text { (Minutes) }\end{array}$ \\
\hline RP1 & Responsible Tourism and Certification Expert & 30 \\
\hline RP2 & Pro-Poor and Sustainable Tourism Expert & 80 \\
\hline RP3 & Co-Founder CBT-I and CBT Expert & 30 \\
\hline RP4 & Programme Coordinator INDECON & 35 \\
\hline RP5 & Former Programme Coordinator CCBEN & 25 \\
\hline RP6 & Co-Founder CBT-I, Former CEO CBT-I & 40 \\
\hline
\end{tabular}


Table 6: ASEAN-CBTS Criteria (Source: Adapted from Carter, 2014).

\begin{tabular}{|l|}
\hline Criteria \\
\hline 1. Community Ownership and Management \\
\hline 2. Contribution to Social Well-Being \\
\hline 3. Conserving and Improving the Environment \\
\hline 4. Encouraging Interaction between the Local Community and Guests \\
\hline 5. Quality Tour and Guiding Services \\
\hline 6. Ensuring Quality Food and Beverage Services \\
\hline 7. Ensuring Quality Accommodations \\
\hline 8. Ensuring Performance of (in-bound) CBT Friendly Tour Operators (FTO) \\
\hline
\end{tabular}

